\title{
KARAKTERISTIK DAN PERAN KYAI DALAM SOSIALISASI PERILAKU HIDUP BERSIH DAN SEHAT (PHBS) DI PESANTREN
}

\author{
Uud Wahyudin, Agus Setiaman \\ Universitas Padjdjaran
}

\begin{abstract}
ABSTRAK
Penelitian yang berjudul faktor-faktor karakteristik dan peranan kyai dalam sosialisasi perilaku hidup bersih dan sehat di lingkungan pesantren ini bertujuan untuk mengetahui karakteristik dan peranan kyai dalam sosialisasi PHBS. Penelitian ini menggunakan metode kuantitatif dengan menguji hubungan antar variabel untuk memperoleh hubungan antara faktor-faktor internal, faktor-faktor eksternal, pengetahuan dan sikap kyai terhadap PHBS dengan tingkat peranannya dalam sosialisasi PHBS di pesantren. Data diperoleh dengan penyebaran angket ke sejumlah kyai di beberapa pesantren di Kecamatan Jampang Tengah dengan menggunakan teknik sampling strata proporsional. Dari penelitian ini diharapkan akan muncul beberapa hubungan antara karakteristik dan peranan kyai dalam sosialisasi PHBS di pesantren. Sehingga memberikan gambaran mengenai kondisi kyai dalam peranannya sebagai komunikator sosialisasi PHBS di pesantren yang kemudian pada gilirannya gambaran ini diharapkan dapat dijadikan rujukan pengambil keputusan bidang kesehatan dalam melakukan kampanye komunikasi PHBS di institusi pendidikan/ pesantren secara lebih baik agar dapat menjadi komunikator kesehatan yang lebih persuasif.
\end{abstract}

Kata-kata Kunci: PHBS, Peran Kyai, Komunikasi Kesehatan

\section{THE CHARACTERISTICS AND ROLE OF KYAI IN SOCIALIZING HEALTH AND CLEAN BEHAVIOR (PHBS) IN ISLAMIC BOARDING SCHOOL}

\begin{abstract}
This study entitled Characteristic Factors and the Role of Kyai in Socializing Clean and Healthy Behavior in Islamic Boarding Schools (Correlational Study in Jampang Tengah District, Sukabumi Regency). It aims to determine the characteristics and roles of Kyai in PHBS socialization. This study uses a quantitative method by testing the relationship between variables to obtain a relationship between internal factors, external factors, knowledge and attitudes of the kyai towards PHBS with the level of their role in the socialization of PHBS in boarding schools. Data were obtained by distributing questionnaires to a number of kyai in several Islamic boarding schools in Jampang Tengah District using proportional strata sampling techniques. From this research, it is expected that some relationships will emerge between the characteristics and role of the kyai in the dissemination of PHBS in boarding schools. So as to give an idea of the condition of the kyai in their role as communicators of PHBS socialization in boarding schools which in turn this image is expected to be used as a reference for health decision makers in conducting PHBS communication campaigns in educational institutions in order to become more persuasive health communicators.
\end{abstract}

Keywords: PHBS, Role of Kyai, Health Communication

Korespondensi: Dr. Uud Wahyudin, M.Si. Universitas Padjadjaran. Jl. Raya Bandung Sumedang KM.21, Hegarmanah, Jatinangor, Kabupaten Sumedang, Jawa Barat 45363 Email: uudwahyudin@ yahoo.co.id 


\section{PENDAHULUAN}

Kita masih ingat bahwa sejak dulu, sering muncul stigma "santri budug", "santri kudis", dan julukan-julukan negatif lainnya terhadap pesantren. Memang, berbagai fakta menunjukkan di pesantren-pesantren di perdesaan (pesantren tradisional) masih ditemukan fakta tidak bersihnya santri dalam berperilaku hidup sehari-hari. Perilaku yang tidak sehat tersebut mempermudah penularan penyakit kulit di kalangan santri.

Hal ini sejalan dengan pendapat Iskandar (2000) dalam Rohmawati (2010:3), bahwa timbulnya penyakit kulit skabies (budug) disebabkan santri memiliki kebiasaan hidup kurang bersih dan kebiasaan hidup yang sudah terpola. Kehidupan secara bersama dan melakukan kontak langsung yang relatif erat menjadi salah satu faktor yang dominan. Penularan secara langsung penyakit skabies terjadi saat kontak kulit dengan kulit. Penularan secara tidak langsung bisa terjadi melalui saling pinjam pakaian, sprei digunakan secara bersama-sama, handuk dipakai oleh beberapa orang, dan sebagainya. Penularan penyakit ini sangat mudah. Antara lain melalui faktor penyebarannya seperti kebersihan diri inidividu yang jelek dan tidak sehatnya lingkungan. Penyakit skabies pada umumnya memang menyerang kehidupan pada suatu kelompok seperti halnya pesantren (Rohmawati, 2010:1).

Munculnya stigma "santri budug" dan berbagai penyakit kulit di pesantren tradisional tentunya tidak sejalan dengan kehadiran kyai atau ulama di pesantren. Sebagai tokoh masyarakat, kyai atau ulama dipandang sebagai pemimpin (pemimpin informal) bagi anggota masyarakat di sekelilingnya. Nasihat serta anjurannya senantiasa ditaati oleh para pengikutnya dan oleh karena itu kyai atau ulama dianggap memiliki kemampuan untuk menyampaikan pendapat-penda-patnya. Ketokohan ulama atau kyai dalam suatu sistem sosial didukung oleh banyak faktor. Hasil pengamatan Horikoshi di Jawa Barat (Ziemek, 1986:194-195) menunjukkan bahwa faktor-faktor pendukung ketokohan ajengan atau ulama adalah kelebihan-kelebihan yang dimilikinya dibandingkan dengan masyarakat di sekitarnya. Oleh karena itu, kyai atau ulama dituntut untuk memiliki kemampuan kepemimpinan pendapat. Termasuk kemampuan kepemimpinan pendapat kyai atau ulama dalam bidang kesehatan.

Sementara itu, munculnya berbagai jenis penyakit di pesantren tentunya tidak sesuai dengan harapan program (PHBS) di Jawa Barat seperti yang sudah menjadi program dinas kesehatan maupun puskesmas. Diharapkan PHBS di Jabar dapat menjadi salah satu upaya untuk mencegah berbagai penyakit yang kerap muncul. Gubernur Jabar Ahmad Heryawan menyampaikan sebuah gagasan dalam mengampanyekan PHBS. Kebiasaan masyarakat untuk melakukan PHBS menjadi permintaan Gubernur Jabar. Menurut Gubernur, kampanye atau sosialisasi PHBS harus terus dilakukan (Pikiran Rakyat, 3 Maret 2009).

$$
\text { Upaya melaksanakan kampanye }
$$
komunikasi PHBS harus ditempuh melalui perluasan jangkauannya. Salah satu kebijakan perluasannya adalah adanya partisipasi aktif kyai 
atau ulama dalam memberikan informasi dan komunikasi tentang pesan-pesan yang berkaitan dengan PHBS, menggerakkan motivasi dan mempengaruhi individu/ masyarakat. Para santri harus memiliki peran dan terlibat langsung dalam mengelola dan membudayakan PHBS.

Hal inilah yang menarik untuk dikaji, di satu sisi pemerintah daerah Jawa Barat terus berupaya mencegah berbagai penyakit yang kerap muncul di tengah masyarakat melalui program PHBS, namun di sisi lain kyai atau ulama dengan berbagai kelebihannya masih belum mampu menyosialisasikan kesadaran kepada para santrinya tentang pentingnya perilaku hidup bersih dan sehat.

Alhasil, pelibatan kyai dalam mengelola kegiatan sosialisasi PHBS di lingkungan pesantren harus mendapat perhatian serius. Kyai harus memiliki pengetahuan mengenai PHBS. Bersikap positif terhadap PHBS. Faktor internal dan faktor eksternal yang dimiliki kyai berhubungan dengan tercapainya harapan tercapainya PHBS di lingkungan pesantren di perdesaan.

Bertitik tolak dari berbagai kecenderungan tersebut, maka tujuan dilakukannya penelitian ini adalah (1) untuk mengetahui tingkat peranan kyai dalam sosialisasi PHBS di pesantren perdesaan, (2) untuk mengetahui pengetahuan dan sikap kyai di pesantren perdesaan tentang PHBS, dan (3) untuk mengetahui hubungan antara faktor-faktor internal, faktor-faktor eksternal, pengetahuan dan sikap kyai terhadap PHBS dengan tingkat peranannya dalam sosialisasi PHBS di pesantren perdesaan.

\section{METODE}

Penelitian survei dirancang dalam penelitian ini karena penelitian ini bersifat penelitian penjelasan (explanatory research), yakni dirancang bisa memberikan penjelasan mengenai hubungan antarvariabel serta dilakukan pengujian hipotesis (Singarimbun, 1989:5). Pendeskripsian data yang berhubungan dengan variabel penelitian dilakukan terlebih dahulu dan selanjutnya dilakukan sebuah analisis data yang menguji hubungan antarvariabel. Penelitian ini disebut juga sebuah riset yang bersifat deskriptif korelasional (Rahmat, 1991:7).

\section{HASIL DAN PEMBAHASAN}

Partisipasi aktif para ulama atau kyai dalam sosialisasi promosi kesehatan bisa dilakukan bila kyai memiliki pengetahuan tentang PHBS, terbentuk sikap positif para kyai terhadap PHBS, serta kyai menerima dan melaksanakan PHBS. Artinya kyai berperan dalam sosialisasi PHBS sangat ditentukan oleh kondisi kognitif dan afektif mereka. Persoalannya, apakah sikap negatif pemuka agama terhadap PHBS itu disebabkan oleh sedikitnya pengetahuan mengenai PHBS ataukah sebaliknya, sebab pada kenyataannya, tidak sedikit ulama atau kyai yang tetap teguh melaksanakan perilaku yang tidak bersih dan sehat meskipun penerangan PHBS kepadanya telah sering dilakukan.

Pendidikan formal memiliki peran penting bagi kyai atau ulama sebagai bekal untuk memberikan pengetahuan dan seluruh 
kemampuannya kepada santri di pesantren, berkaitan dengan kampanye PHBS.

Terpaan media massa, yaitu frekuensi dan intensitas responden dalam membaca surat kabar/majalah, mendengarkan siaran radio, dan menonton siaran televisi dalam upaya memperoleh informasi-informasi pembangunan, termasuk informasi mengenai PHBS. Media massa semestinya diperhatikan karena dapat mempengaruhi masyarakat (Wahyudin,Ronauli, Elita, Mirawati, 2016:125). Demikian juga dengan film, merupakan media persuasi yang ampuh (Barezki \& Hafiar, 2016:1). Interaksi dengan sesama tokoh masyarakat dan petugas pemerintah, yakni pola hubungan antara responden dengan sesama tokoh masyarakat dan petugas pemerintah, terutama dengan Petugas Lapangan Kesehatan/ puskesmas.

Ulama atau kyai adalah seseorang yang bisa menyatukan semua unsur dalam tatanan sosial pedesaan. Umumnya, kyai adalah pemimpin agama dari keluarga di perdesaan yang memiliki pengaruh secara tradisional (Ziemek, 1986:136). Sebagai tokoh masyarakat, kyai atau ulama dapat berperan sebagai "penjaga gerbang" atau gate keeper dalam meng-hadapi ide-ide baru (inovasi) yang masuk ke dalam sistem sosialnya. Peranan kyai atau ulama sebagai "penjaga gerbang" sistem sosial akan diikuti oleh peranannya sebagai legitimator yang akan melakukan kegiatan meligitimasi terhadap suatu inovasi. Menurut Rogers dan Shoemaker (1987:61), dalam proses pengambilan keputusan inovasi kolektif, legitimator menjadi kunci utama dalam inovasi.
Inovasi kolektif yang diadopsi secara cepat berhubungan dengan terlibatnya orang yang memberikan legitimasi dalam sistem sosial untuk mengambil keputusan. Artinya, semakin pengambil keputusan terlibat dalam proses pengambilan keputusan, maka akan semakin cepat tersebarnya inovasi. Sebaliknya, apabila legitimator diabaikan maka mereka cenderung akan berusaha untuk menghalangi innovasi daripada mendukungnya.

Hal ini diperkuat oleh pendapat Rogers dan Shoemaker (1987:108-109) yang mencatat bahwa agen pembaru harus mengenal dan mampu menggerakkan para tokoh masyarakat setempat karena sangat menentukan keberhasilan kampanye difusi (Suryana, Sugiana, Trulline, 2016:5). Agen pembaru harus dapat mempengaruhi tokoh masyarakat melalui komunikasi yang terarah dan usaha yang terpusat sehingga dapat menghemat tenaga, biaya, dan waktu. Agen pembaru tidak perlu berinteraksi satu per satu dengan anggota sistem sosial apabila mampu mempengaruhi tokoh masyarakat. Selanjutnya, ide-idenya terlindungi dari tantangan. Dengan demikian, kemungkinan pengadopsian inovasi akan lebih meningkat.

Sebagai agen pembaru, kyai dapat berkomunikasi dan bekerjasama dengan pemimpin pendapat (opinion leader) mengenai ide-ide kesehatan bagi santri. Seperti ditulis oleh Depari dan Andrews (1978:23) bahwa sebuah prakarsa bisa muncul dari pemimpin pendapat dalam mengomunikasi dan menyebarluaskan pesan-pesan pembangunan melalui berbagai kesempatan (Depari dan Andrews, 1978:23). 
Pengetahuan tentang PHBS, yaitu pengetahuan responden mengenai PHBS baik dalam arti tahu tentang adanya program atau kampanye PHBS, pengetahuan teknis cara-cara melakukan kegiatan PHBS, maupun pengetahuan prinsip-prinsip hidup bersih dan sehat.

Sikap terhadap PHBS, yaitu predisposisi responden terhadap program atau kampanye PHBS yang dinyatakan dalam pernyataan setuju atau tidak setuju terhadap PHBS. Pengukuran dilakukan dengan menggunakan skala berjenjang tiga, yakni dengan cara memberikan angka skor pada stiap kategori jawaban yang diberikan.

\section{Tabel 1}

\section{Pengetahuan dan Sikap Ulama atau Kyai dalam Sosialisasi PHBS di Pesantren Perdesaan}

\begin{tabular}{|c|c|c|c|}
\hline No. & Kategori & F & $\%$ \\
\hline 1 & Sedang & 13 & 31.0 \\
\hline 2 & Tinggi & 29 & 69.0 \\
\hline & Total & 42 & 100.0 \\
\hline
\end{tabular}

Tabel 1 mengindikasikan bahwa secara umum sikap pemuka agama terhadap kampanye komunikasi PHBS berada dalam kategori tinggi. Sikap pada membentuk sikap individu-individu terhadap seuatu. Sikap adalah rasa suka atau tidak suka setiap individu atas sesuatu. Sikap sering dianggap memiliki tiga komponen yaitu kognitif (keyakinan tentang sesuatu), komponen afektif (perasaam suka), dan konatif yang berarti kecenderungan untuk bertindak (Azwar, 2003:5). Faktor-faktor sikap terdiri dari (1) Kognisi, yaitu komponen kognisi merupakan sebuah perasaan yakin. Dengan demikian, mengomunikasikan ide kesehatan dilakukan melalui penyampaian informasi-informasi yang mempenagruhi kognisi masyarakat. Sosialisasi PHBS pada santri di pondok pesantren harus memenuhi kebutuhan informasi dan sosialisasi juga harus mampu memberikan pengetahuan serta pemahaman santri tentang PHBS. Kebutuhan terhadap informasi PHBS seharusnya memuaskan rasa ingin tahu para santri di pesantren di perdesaan, (2) afeksi, secara umum dapat dikatakan bahwa komponen afektif adalah peasaan yang dimiliki setiap individu terhadap sesuatu. Komponen afeksi adalah perasaan suka atau emosi terhadap PHBS. Bila santri merasa suka terhadap informasi yang berkaitan dengan PHBS maka informasi kesehatan tersebut harus dapat memberikan rasa suka atau senang dan sesuai dengan pengalaman-pengalaman yang disukai para santri, (3) konatif, adalah kemampuan konasi dalam struktur sikap menunjukan bagimana perilaku atau keseimbangan berprilaku dalam diri individu-individu berkaitan dengan objek sikap yang dihadapi.

Keterlibatan para ulama atau kyai dalam sosialisasi atau kampanye PHBS dapat mempercepat proses perluasan jangkauan PHBS khususnya di pesantren. Peran aktif kyai dalam mengelola kampenye PHBS di pesantren akan semakin mempermudah terwujudnya tujuan kampanye PHBS.

Peranan kyai dalam pelaksanaan sosialisasi PHBS ditentukan seberapa besar pengetahuan dan sikap mereka tentang informasi PHBS. Artinya sosialisasi PHBS di pesantren sangat bergantung 
pada sikap kyai terhadap pentingnya melakukan PHBS dalam kehidupan pesantren. Persoalannya, apakah sikap negatif kyai atau ulama terhadap PHBS itu disebabkan oleh sedikitnya pengetahuan mengenai PHBS ataukah sebaliknya, sebab pada kenyataannya, tidak sedikit kyai atau ulama yang tetap teguh menolak program PHBS meskipun penerangan PHBS kepadanya telah sering dilakukan.

Penolakan beberapa kyai atau ulama terhadap PHBS sudah terjadi sejak awal perkembangannya, karena selama ini pesantren lebih banyak dijumpai karena sering munculnya berbagai penyakit seperti "budug”, koreng, kusta, dan penyakit kulit lainnya, sehingga pada waktu itu tidak sedikit kyai atau ulama yang menolak PHBS dan menganjurkan kepada masyarakat di sekelilingnya agar tidak menerima PHBS. Kita masih ingat adanya stigma "santri budug", "pesantren kurap", dan julukan-julukan negatif lainnya.

Variabel tak bebas (variabel dependen) penelitian ini adalah peranan ulama atau kyai dalam sosialisasi PHBS di pesantren. Peranan kyai atau ulama dalam sosialisasi PHBS dimaksudkan sebagai manifestasi perilaku dalam bentuk peranserta atau partisipasi mereka dalam menyampaikan informasi atau pesan-pesan PHBS kepada para santri agar mereka memiliki pengetahuan dan pemahaman tentang PHBS (peranan sebagai komunikator), memotivasi santri untuk menerima dan melaksanakan PHBS dengan sukarela (peranan sebagai motivator), menghubungkan santri yang ingin memahami dan menjadi sukarelawan PHBS dengan para petugas kesehatan, baik petugas kesehatan dari puskesmas, tenaga medis, bidan desa, maupun Dokter dan Bidan Praktek Swasta (peranan sebagai mediator), dan melegitimasi PHBS untuk diadopsi oleh santri (peranan sebagai legitimator).

Tabel 2

Tingkat Peranan Kyai Dalam Sosialisasi PHBS

\begin{tabular}{|l|l|r|r|}
\hline No. & Kategori & \multicolumn{1}{|c|}{ F } & \multicolumn{1}{c|}{$\%$} \\
\hline 1 & Rendah & 1 & 2.4 \\
\hline 2 & Sedang & 16 & 38.1 \\
\hline 3 & Tinggi & 25 & 59.5 \\
\hline & Total & 42 & 100.0 \\
\hline
\end{tabular}

Peranan kyai atau ulama sebagai pemuka agama dalam pembangunan pedesaan dapat ditunjukkan melalui partisipasinya dalam pelaksanaan pembangunan tersebut. Partisipasi merupakan wujud nyata dari pelaksanaan peran yang harus dilakukan oleh seseorang yang menempati kedudukan tertentu (Pareek, 1985:4). Menurut Ndraha (1982:9), salah satu unsur pokok dalam pelaksanaan program-program pembangunan masyarakat desa adalah adanya partisipasi masyarakat itu sendiri. Hal itu disebabkan bahwa pada dasarnya pembangunan masyarakat desa ditujukan untuk menciptakan kondisi yang memungkinkan terwujudnya partisipasi untuk memba-ngun lingkungan mereka (Yakub, 1985:19).

Berdasarkan perhitungan hasil uji korelasi diperoleh hasil bahwa terdapat hubungan aktor internal (pendiidkan formal) dengan peranan ulama 
dan kyai dalam sosialisasi PHBS di pesantren perdesaan, yaitu (1) terdapat hubungan yang sangat lemah antara faktor internal (pendiidkan formal) dengan peranan ulama dan kyai dalam sosialisasi PHBS di pesantren pedesaan, (2) nilai signifikansi r-hitung sebesar 0.320 yang memiliki arti bahwa hubungan tersebut tidak signifikan

\section{Tabel 3 Keterkaitan Pendidikan Formal dengan Peranan Kyai}

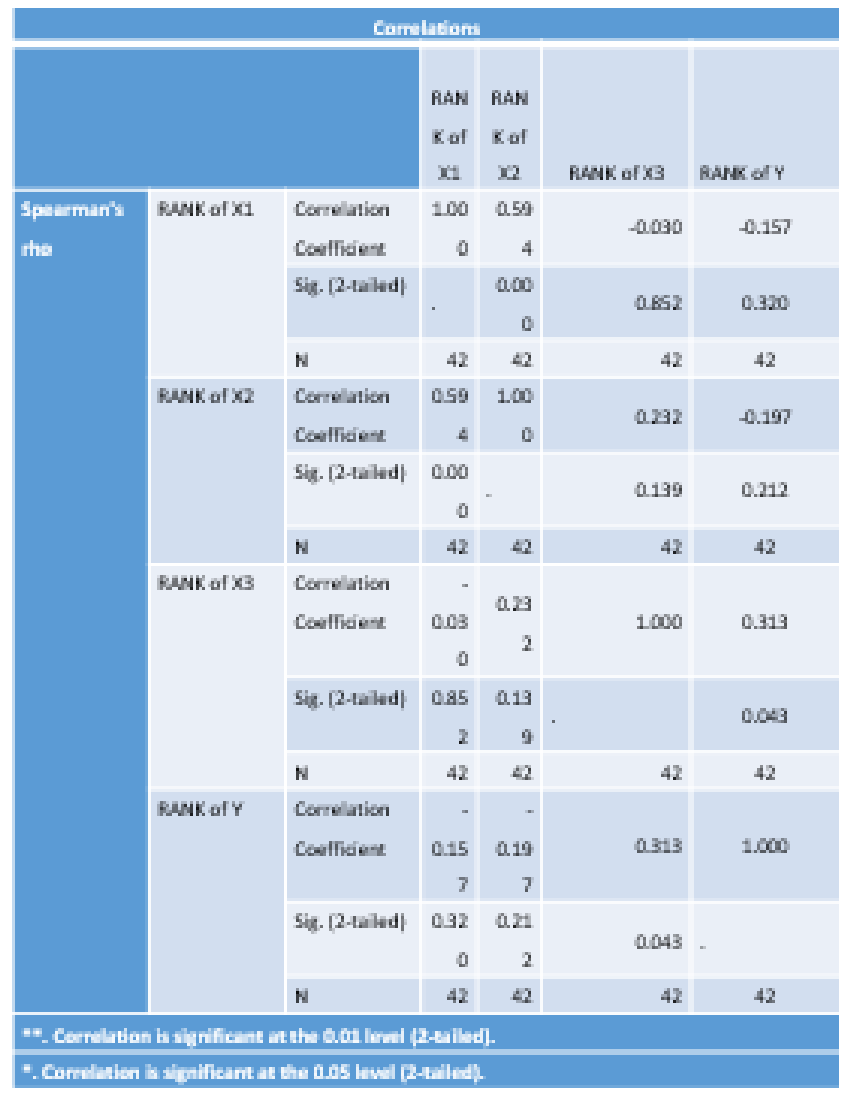

Hubungan faktor eksternal dengan peranan ulama atau kyai dalam sosialisasi PHBS di pesantren pedesaan, yaitu (1) terdapat hubungan yang sangat lemah antara faktor eksternal dengan peranan ulama atau kyai dalam sosialisasi PHBS di pesantren pedesaan, (2) nilai signifikansi r-hitung sebesar 0.212 yang memiliki arti bahwa hubungan tersebut tidak signifikan.
Hubungan pengetahuan dan sikap ulama dan kyai dengan peranan dalam sosialisasi PHBS di pesantren pedesaan, yaitu (1) terdapat hubungan yang cukup antara pengetahuan dan sikap dengan peranan ulama dan kyai dalam sosialisasi PHBS di pesantren pedesaan, (2) nilai signifikansi r-hitung sebesar 0.043 yang memiliki arti bahwa hubungan tersebut signifikan.

Keterkaitan antara faktor pengetahuan dan sikap ulama terdapat hubungan cukup kuat dan signifikan dengan peranan ulama dan kyai dalam sosialisasi PHBS di pesantren pedesaan.

Keberadaan ulama sebagai orang yang menguasai ilmu keagamaan secara mendalam akan menempatkannya ke dalam posisi sebagai tempat bertanya bagi orang-orang di sekitarnya. Dengan demikian, seorang ulama dapat dipandang sebagai seorang tokoh dalam masyarakat yang bersangkutan. Ketokohan ulama dalam masyarakat juga didukung oleh fungsinya sebagai ulama. Buchori (1987:3) menyatakan bahwa fungsi ulama di tengah-tengah masyarakat adalah membimbing umat dalam kehidupan sehari-hari, agar segenap perbuatan umatnya sesuai dengan ajaran agama (Islam). Fungsi membimbing dalam hal ini berarti menyertai umat dalam menempuh suatu perjalanan batin. Selanjutnya ditegaskan bahwa mantap tidaknya bimbingan yang diberikan oleh ulama kepada umatnya, terutama ditentukan oleh ada tidaknya pemahaman yang memadai dari pihak ulama terhadap persoalan zaman yang sedang berlangsung. Ulama yang paham akan persoalan zaman akan mampu memberikan bimbingan yang relevan dengan persoalan yang sedang dihadapi 
oleh umat. Dengan kata lain, seorang ulama harus mampu bersikap antisipatif dan responsif terhadap tanda-tanda zaman, sehingga dapat membantu umat dalam memecahkan persoalan yang dihadapinya.

Zaini (1987:48) mengungkapkan bahwa dalam keulamaam itu ada dua dimensi: dimensi keilmuan dan kepemimpinan. Di dalam menyoroti kedudukan ulama sebagai pembimbing masyarakat, Buchori (1987:5-7) menyatakan bahwa:

"Sebagai pembimbing masyarakat ulama harus mampu untuk membimbing masyarakat dalam mengembangkan sikap yang sehat, sikap yang dewasa, dan mengem-bangkan tekad yang kuat untuk bertindak bersama-sama secara strategis dalam mengejar ketinggalan-ketinggalan baik yang dialami oleh masyarakat itu sendiri maupun oleh bangsa Indonesia secara keseluruhan. Oleh karena itu, para ulama dituntut untuk memiliki kemampuan dalam menjelaskan kepada masyarakat tentang ciri-ciri pokok atau gambaran global tentang masayarakat modern yang sesuai dengan ajaran Islam: bagaimana ciri-ciri dasar sistem pengolahan informasi; bagaimana kedudukan ilmu pengetahuan dalam sistem pendidikan; bagaimana sistem ekonomi yang harus dikembangkan; bagaimana sistem yang harus dikembangkan antara umara, ulama dan umat; dan sebagainya."

Keberadaan ulama sebagai orang yang menguasai ilmu keagamaan secara mendalam akan menempatkannya ke dalam posisi sebagai tempat bertanya bagi orang-orang di sekitarnya. Dengan demikian, seorang ulama dapat dipandang sebagai seorang tokoh dalam masyarakat yang bersangkutan. Ketokohan ulama dalam masyarakat juga didukung oleh fungsinya sebagai ulama. Buchori (1987:3) menyatakan bahwa fungsi ulama di tengah-tengah masyarakat adalah membimbing umat dalam kehidupan sehari-hari, agar segenap perbuatan umatnya sesuai dengan ajaran agama (Islam). Fungsi membimbing dalam hal ini berarti menyertai umat dalam menempuh suatu perjalanan batin. Selanjutnya ditegaskan bahwa mantap tidaknya bimbingan yang diberikan oleh ulama kepada umatnya, terutama ditentukan oleh ada tidaknya pemahaman yang memadai dari pihak ulama terhadap persoalan zaman yang sedang berlangsung. Ulama yang paham akan persoalan zaman akan mampu memberikan bimbingan yang relevan dengan persoalan yang sedang dihadapi oleh umat. Dengan kata lain, seorang ulama harus mampu bersikap antisipatif dan responsif terhadap tanda-tanda zaman, sehingga dapat membantu umat dalam memecahkan persoalan yang dihadapinya.

\section{PENUTUP}

Berdasasarkan penelitian yang dilakukan maka diperoleh kesimpulan (1) tingkat peranan pemuka agama dalam pelaksanaan kampanye komunikasi PHBS di Kecamatan Jampang Tengah Kabupaten Sukabumi berada dalam kategori tinggi, (2) sikap pemuka agama terhadap kampanye komunikasi PHBS di Kecamatan Jampang Tengah kabupaten Sukabumi berada dalam kategori baik, (3) semakin tinggi faktor internal dan eksternal yang dimiliki kyai maka semakin tinggi pula 
tingkat peranan pemuka agama dalam kampanye PHBS di pesantren perdesaan.

Penelitian menunjukkan bahwa (1) perlu dukungan berbagai pihak, khususnya stakeholder bidang kesehatan dalam membuat kebijakan yang mendukung kampanye PHB, (2) seyogyanya pihak tenaga profesional di bidang kesehatan lebih proaktif dalam mendukung setiap kampanye kesehatan, khususnya yang melibatkan pihak pemuka agama, (3) diperlukan penelitian lanjutan untuk mengetahui kampanye komunikasi kesehatan yang dilakukan pihak/ dinas kesehatan di kecamatan Jampang Tengah kabupaten Sukabumi, (4) tahapan berikutnya yang harus dilakukan adalah penelitian yang berkaitan dengan kampanye PHBS yang dilakukan secara bersama-sama antara dinas kesehatan dengan pesantren.

\section{DAFTAR PUSTAKA}

Abidin, Zainal. 2006. Zikir Suatu Tradisi Pesantren Menuju Terapeutik Depresif. Jurnal IBDA Purwokerto.

Barezki, F.E., Hafiar, H., 2016, Proses Persuasi Ruang Film Bandung Kepada Komunitas Film Bandung dalam Program klinik Film, diakses dari Jurnal ProTVF Vol 1 No 1, doi http://dx.doi.org/10.24198/ptvf.v1i1.13328

Davis, K., dan J.W. Newstrom. 1990. Perilaku Organisasi. Erlangga, Jakarta.

Hornik, Robert. 2002. Public Health Communication. Lawrence Publishers, London

Liliweri, Alo. 2009. Komunikasi Kesehatan. Bandung: Citra Aditia Bakti.

Pareek, U. 1985. Mendayagunakan Peran-peran Keorganisasian. PT. Pustaka Binaman Pressindo, Jakarta.
Rahman, A. 1991. Pola Pencarian Informasi Pertanian terhadap Tingkat Pengetahuan Petani dalam Meningkatkan Produksi Pertanian. Universitas Padjadjaran, Bandung.

Rakhmat, J. 1991. Psikologi Komunikasi. Remaja Rosdakarya, Bandung.

1989. Metode Penelitian Komunikasi. Remaja Rosdakarya: Bandung

Rohmawati, Riris Nur. 2010. Skripsi. Hubungan antara Faktor Pengetahuan dan Perilaku dengan Kejadian skabies di Ponpes AlMuayyad Surakarta.

Rustandi, Dudi. 2009. Paradigma Komunikasi Kesehatan. Jurnal Observasi. Bandung.

Schiavo, Renata. 2007. Health Communication. Sage Publications, New Delhi

Singarimbun, Masri. 1989. Metode Penelitian Survei. Jakarta.

Suryana, A., Sugiana, D., Trulline, P., 2016, Pengaruh Atribut Agen Perubahan (Agent of Change ) Pendamping Program Keluarga Harapan (PPKH) terhadap Perubahan Sikap Rumah Tangga Sangat Miskin (RTSM) Peserta Program Keluarga Harapan (PKH) di Kabupaten Bandung, diakses dari Jurnal Manajemen Komunikasi Vol 1 No 1, doi http://dx.doi.org/10.24198/jmk.v1i1.10061

Thoha, M. 1983. Perilaku Organisasi: Konsep Dasar dan Aplikasinya. Rajawali Press, Jakarta.

Venus, Antar. 2004. Manajemen Kampanye. Bandung: Simbiosa Rekatama Media.

Ziemek, M. 1986. Pesantren dalam Perubahan Sosial. Perhimpunan Pengem-bangan Pesantren dan Masyarakat (P3M), Jakarta.

Wahyudin, U., Ronauli, M., Elita, F.M., Mirawati, I., 2016, HUBUNGAN ANTARA PESAN KAMPANYE 9 AKSI RAMAH LINGKUNGAN DI AKUN TWITTER 
EARTH HOUR BANDUNG DENGAN SIKAP FOLLOWERS AKTIF TERHADAP GAYA HIDUP RAMAH LINGKUNGAN, diakses dari Jurnal Manajemen Komunikasi 'Vol 1 No 1,

doi http://dx.doi.org/10.24198/jmk.v1i1.11017 